\title{
The Process of Investigation on Criminal Currency
}

\section{Beni Aji*) And Lathifah Hanim*)}

*) Student of Master of Law, Faculty of Law, Universitas Islam Sultan Agung Semarang and Indonesian Police, E-mail: beniaji30@gmail.com

$\left.{ }^{* *}\right)$ Faculty of Law, Universitas Islam Sultan Agung Semarang

\begin{abstract}
.
The objectives of this study are as follows: To identify and analyze the investigation process of currency crimes. To find out and analyze obstacles to the process of investigating currency crimes. To find out and analyze solutions to overcome barriers to the investigation of currency crimes. The method used by researchers is juridical sociological approach to law and The specifications in this research are descriptive. Based on the results of that research The process of investigating currency crimes actions in the form of: (a) arrest; (b) Detention; (c) Confiscation of evidence; (d) Witness examination; (e) Examination of the suspect ( $f$ ) Then a discussion is conducted in the form of case analysis and juridical analysis; (g) Making a resume by the assistant investigator/investigator and then drawing a conclusion. The obstacles are: First, the lack of coordination between law enforcement officers. Second, the weakness of investigations against perpetrators who are categorized as perpetrators. Third, investigations currently carried out by investigators are limited to the perpetrators who destroyed rupiah banknotes, resulting in difficulties in fulfilling the subjective element, namely mens rea. Solutions include: a) Overcoming crimes committed by the Indonesian National Police for destroying rupiah banknotes. b) Regional and international police cooperation can be carried out through Interpol, other government agencies or directly.
\end{abstract}

Keywords: Investigation; Crime; Currency.

\section{Introduction}

The Unitary State of the Republic of Indonesia as an independent and sovereign country has a symbol of state sovereignty that all Indonesian citizens must respect and be proud of. One of the symbols of the country's sovereignty is currency. The currency issued by the unitary state of the Republic of Indonesia is the rupiah. Rupiah is used as a legal means of payment in national economic activities in order to create social welfare for all Indonesian people.

The issuance of Act No. 7 of 2011 concerning Currency is based on the consideration that the rupiah is one of the symbols of state sovereignty that all Indonesian citizens must respect and be proud of. The use and role of money that continues to grow, is one reason why the importance of rules regarding this currency. The management of the economy cannot be separated from the role of money. For this reason, money management must also be continuously improved, one of the ways is by forming laws. The presence of Act No. 7 of 2011 concerning Currency is one way to create better legal regulations regarding rupiah management.

Money is a flexible medium of exchange because it can be exchanged for any kind of living necessities, anywhere. With money it can be used to buy various things, both movable and immovable goods. In addition, money can also be used to 
pay fees for services such as transportation fees, banking services, building construction services, telephone services, and other services. ${ }^{1}$

The role of money is very important in the country's economy because money has several functions, including as a means of exchange or means of paying and measuring prices so that it can be said that money is one of the main tools of the economy. Currency that supports the economy of a country will run well so that it supports the achievement of the goals of the state, namely achieving a just and prosperous society. In addition, if viewed specifically from the monetary sector, the amount of money circulating in a country must be managed properly in accordance with the needs of the economy.

The characteristics of this special characteristic are open, semi-closed and closed. This special characteristic is used in order to recognize the rupiah from counterfeiting in the form of imitating currency. ${ }^{2}$ Currency counterfeiting is classified as a crime. ${ }^{3}$

The modes and forms of crimes against currency, especially the destruction of rupiah banknotes, are increasingly developing. Meanwhile, the provisions for the crime of destroying rupiah banknotes as stipulated in the Criminal Code are deemed not to comprehensively regulate the types of actions and sanctions that are threatened. With this premise, the birth of a new legal regulation that discusses the rupiah as the currency of Indonesia, along with the prohibitions and sanctions in a law, is expected to be a new step in the effort to eradicate the criminal act of destroying rupiah banknotes in Indonesia.

The objectives of this study are as follows: To identify and analyze the investigation process of currency crimes. To find out and analyze obstacles to the process of investigating currency crimes. To find out and analyze solutions to overcome barriers to the investigation of currency crimes.

\section{Research methods}

The approach method used in this research is a sociological juridical method (Sociological Research) which emphasizes practice in the field related to aspects of the law or legislation that applies to the object of research being discussed and looks at the legal norms that apply and is then linked with the facts and facts contained in people's lives and discusses how hum operates in society. ${ }^{4}$ This research is a descriptive study, namely research that describes the characteristics of an individual, the circumstances and symptoms of a particular group to determine the spread of a social phenomenon in society.

\section{Result and Discussion}

\subsection{Currency Crime Investigation Process}

\footnotetext{
${ }^{1}$ Supramono, Gatot. (2014). Hukum Uang Di Indonesia. Bekasi: Gramata Publising. p. 9.

2 Shadily, Hassan. (2000). Kamus Besar Bahasa Indonesia. Jakarta: Gramedia. p. 369.

${ }^{3}$ Mulyanto in Faisal Salam. (2004). Pemberantasan Tindak Pidana Korupsi. Bandung: Pustaka. p. 84

${ }^{4}$ Amuruddin and Zainal Asikin. (2003). Pengantar Metode Penelitian Hukum. Jakarta: Raja Grafindo Persada. p. 21
} 
In accordance with Article 1 point 2 of the Criminal Procedure Code, it is stated that: Investigation is a series of actions by an investigator in matters and according to methods regulated in this Law to seek and collect evidence which with that evidence sheds light on a criminal act and in order to find the suspect. ${ }^{5}$

In this investigation the police played a role, although it was the prosecutor who would ultimately use the results obtained for the purpose of bringing the defendant to trial. However, it is clear that one cannot do it alone. Therefore, there is assistance from other officials. For the success of the prosecution work, it is only natural that the prosecutor can supervise, coordinate and give instructions to investigating officials who assist in gathering such evidence. ${ }^{6}$

Meanwhile, the process of investigating criminal acts concerning currency includes actions in the form of: (a) The arrest of the suspect, which is then issued an official report of the arrest; (b) The detention of a suspect, which is then made an Official Report of the detention; (c) Confiscation of evidence, which is then made an official report of confiscation; (d) Examination of witnesses so that evidence of the testimony of witnesses is obtained; (e) Examination of the suspect Hasan Basir so that evidence of the suspect's statement is obtained; (f) Then, a case analysis and juridical analysis are carried out. (g) Making a resume by the assistant investigator/investigator and making a conclusion.

\subsection{Barriers to the Investigation Process of Currency Crimes}

Polri's performance improves and strengthens Polri in achieving the common goal of protecting the community. Play a role in preventing the circulation of counterfeit money by providing guidance and counseling, especially for the general public and for institutions conducting financial cooperation with Bank Indonesia. For the issue of extension, the time and place were determined from the results of the evaluation in the areas where counterfeit money was found. ${ }^{7}$

Law enforcement as a process is essentially the application of discretion which involves making decisions that are not strictly regulated by legal principles, but have an element of personal judgment. Thus in essence discretion is between law and morals (ethics in the narrow sense). ${ }^{8}$

Barriers to the investigation of currency crimes include:

- Lack of coordination among law enforcement officers in the field regarding proving currency counterfeiting as an internal obstacle. This is evidenced by the absence of a common perception regarding law enforcement in implementing articles as regulated in the Criminal Code and Act No. 7 of 2011 concerning Currency. To overcome this internal obstacle requires coordination and a memorandum of understanding between law enforcement officials within the

\footnotetext{
5 Sasangka, Hari and Lily Rosita. (2003). Hukum Pembuktian dalam Perkara Pidana. Bandung: Mandar Maju. p. 17.

6 Ibid, p. 26

${ }^{7}$ Maryanto , Danail Arifin, Special Measures for Crime Unit Police Resort Kudus in Law Enforcement of Infringement Currency Crime, Jurnal Daulat Hukum, Vol 2, No 1 (2019): March 2019, Universitas Islam Sultan Agung Semarang http://dx.doi.org/10.30659/jdh.v2i1.4207

8 Soekanto, Soerjono. (2004). Faktor-Faktor yang Mempengaruhi Penegeakan Hukum. Jakarta: Raja Grafindo Persada. p. 7.
} 
framework of the criminal justice system which is aimed at the framework of equality of perceptions to prove criminal acts of destroying banknotes.

- Human Resources (Human resources). This is the cause of the inadequate quality of investigators. Not all investigators have the qualifications of a law degree or at least have mastered the techniques and tactics of investigating the crime of destroying banknotes. According to R. Soesilo, an investigator can be said to be a professional, so he must have extensive knowledge, abilities and skills as well as attitudes and behavior that are consistent with his duties, then in carrying out his duties he will not be successful without the support of adequate equipment and funds if all of these factors can be fulfilled so that it can produce a good quality of professionalism, so the main factor in the professionalism of investigators is the human element in addition to other factors that support it, among others, facilities, ${ }^{9}$

- The low mentality of law enforcement officers. The big problem for the Indonesian nation at this time is the low quality of moral integrity and ethics of law enforcement officers, including law enforcement against currency easing crimes. It is hoped that law enforcement agencies must have two things, namely integrity and professionalism. ${ }^{10}$

- Weak investigations against perpetrators categorized as the perpetrators of the crime of destroying banknotes. This requires proactive action by investigators in disclosing criminal acts of destroying banknotes. This is intended to ensnare the perpetrators who have committed an organized crime of destroying banknotes.

- The investigations currently carried out by investigators are limited to the perpetrators who ravaged banknotes, resulting in difficulties in fulfilling the subjective element, namely mens rea.

- The results of the investigation documents for the destruction of rupiah banknotes can only be submitted to the prosecutor's office if they are complete with evidence.

\subsection{Solutions to Overcome Barriers to Currency Criminal Investigation Process}

Crime is a portrait of the concrete reality of the development of people's lives, which directly or indirectly or is challenging the condition of society, that in the life of society there is a vulnerability gap that has the potential to give birth to individuals behaving deviantly. Within the community there is a struggle for interests which is not always fulfilled in the right way, meaning that there are improper and illegal methods that are carried out by a person or group of people to fulfill their interests. ${ }^{11}$ The threat of transnational, transnational crime has become one of the world's major concerns. Southeast Asia or East Asia, including

\footnotetext{
${ }^{9}$ R. Soesilo. (1980). Taktik dan Teknik Penyidikan Perkara Kriminil. Bogor: Politea. p. 57

10 Opinion, Highlighting the Moral Quality of Law Enforcers, quoted from /www.analisadaily.com/news/read/2011/12/10/, accessed on 29 November 2020, at 20.05 WIB 11 Wahid, Abdul and Mohammad Labib. (2005). Kejahatan Mayantara (Cyber Crime). Bandung: Refika Aditama. p. 134.
} 
Indonesia as a whole, is classified as vulnerable to the threat of transnational crimes, such as money laundering. ${ }^{12}$

The prevailing currency in Indonesia is regulated in Act No. 7 of 2011 concerning 18 Currencies (Currency Law). Article 2 paragraph (1) of the Currency Law states that the currency of the Republic of Indonesia is Rupiah. The rupiah has a characteristic on each rupiah which is determined with the aim of showing identity, differentiating the price or nominal value, and securing the rupiah from counterfeiting. The special characteristics that exist in rupiah are regulated in Article 5 paragraph (3) and (4) of the Currency Law where this special feature is intended as a security and is contained in the design, materials and techniques of the rupiah printing. The characteristics of this special characteristic are open, semi-closed and closed. ${ }^{13}$

In addition to repressive measures, the framework for investigating currency crimes is also necessary for preemptive and preventive measures as follows:

"Pre emtive through outreach and outreach activities include:

- In this activity, efforts are made for the public to know and recognize the characteristics of real money, coins and banknotes of the Republic of Indonesia to gain participation and create immunity from being easily involved in illegal crimes, so that an attitude of participation in tackling counterfeit money crimes can be realized as early detection. if you know there is counterfeit money

- This activity is carried out in integrated collaboration between functions and coordination between sectors by involving spiritual aspects through lectures, mass media exhibitions and others.

- Counseling related to multifunctional machines.

Preventive is done through:

- Security at the official and legal place of making money.

- Supervision of printing companies, sales and trading of printing equipment and infrastructure (data, etc.)

- Monitoring and detection at the center of trade and economy.

- Strict checks at entrances through the Republic of Indonesia and across borders to guard against possible smuggling of counterfeit money.

- Good service to people who report the discovery of counterfeit bills

- Periodic supervision and circulation of multi-functional machines, for the implementation of preventive activities, coordination with various relevant agencies is carried out for accuracy, speed and confidentiality of actions.

Solutions to overcome obstacles in the investigation of currency crimes include:

- Police against the destruction of rupiah banknotes, which in practice requested assistance from Bank Indonesia as the Central Bank and the Attorney General's Office.

\footnotetext{
${ }^{12}$ Sri Endah Wahyuningsih, Rismanto, Criminal Law Enforcement Policy Against Money Laundering in the Context of Reforming Criminal Law in Indonesia, Jurnal Pembaharuan Hukum, Volume II No. January 1 - April 2015

${ }^{13}$ Agus Arif Wijayanto, Currency Counterfeiting as a Crime in Indonesia, Khaira Ummah Legal Journal Vol. 12. No. 4 December 2017
} 
- Police cooperation, both regional and international, can be carried out through Interpol, other government agencies or directly.

\section{Closing}

Based on the descriptions in the discussion, the following conclusions are formulated: The process of investigating criminal acts concerning currency includes actions in the form of: (a) The arrest of the suspect, which is then issued an Official Report of the arrest; (b) The detention of the suspect, which is then made an Official Report of the detention; (c) Confiscation of evidence, which is then made an official report of confiscation; (d) Examination of witnesses so that evidence of the testimony of witnesses is obtained; (e) Examination of the suspect Hasan Basir so that evidence of the suspect's statement is obtained; (f) Then conduct discussion in the form of case analysis and juridical analysis; (g) Making a resume by the assistant investigator/investigator and then drawing a conclusion. Obstacles to the Investigation Process of Currency Crime, namely First, Lack of coordination among law enforcement officers in the field regarding evidence of the destruction of rupiah banknotes, especially against perpetrators categorized as organized crimes. Second, the weakness of the investigations of the perpetrators categorized as the perpetrators of destroying the rupiah banknotes in the proof system. Third, investigations currently carried out by investigators are limited to the perpetrators of destroying rupiah banknotes, resulting in difficulties in fulfilling the subjective element, namely mens rea. Solutions to overcome obstacles in the process of investigating currency crimes include: Handling the crime of destroying rupiah banknotes by the National Police, which in its implementation requested assistance from Bank Indonesia as the Central Bank and the Attorney General's Office.

This research suggests that people treat paper money better (not scribbling, not folding banknotes excessively, not using equipment that can damage money such as staples to put money together, putting banknotes in a proper place. people participate in minimizing the habit of some people who are aware of or do not like to destroy banknotes, which is one of the symbols of our beloved Indonesian state, so that law enforcement against criminals of destroying rupiah banknotes with maximum penalties will provide a deterrent effect on the perpetrators.

\section{References}

\section{Journals}

[1] Agus Arif Wijayanto, Currency Counterfeiting as a Crime in Indonesia, Khaira Ummah Legal Journal Vol. 12. No. 4 December 2017

[2] Maryanto, Danail Arifin, Special Measures for Crime Unit Police Resort Kudus in Law Enforcement of Infringement Currency Crime, Daulat Hukum, Vol 2, No 1 (2019): March 2019, Sultan Agung Islamic University Semarang, http://dx.doi.org/10.30659/jdh.v2i1.4207

[3] Sri Endah Wahyuningsih, Rismanto, Criminal Law Enforcement Policy Against Money Laundering in the Context of Reforming Criminal Law in Indonesia, Jurnal Pembaharuan Hukum Volume II No. January 1 - April 2015 


\section{Books}

[1] Amuruddin and Zainal Asikin. (2003). Pengantar Metode Penelitian Hukum. Jakarta: Raja Grafindo Persada

[2] Mulyanto in Faisal Salam. (2004). Pemberantasan Tindak Pidana Korupsi. Bandung: Pustaka

[3] R. Soesilo. (1980). Taktik dan Teknik Penyidikan Perkara Kriminil. Bogor: Politea

[4] Sasangka, Hari and Lily Rosita. (2003). Hukum Pembuktian dalam Perkara Pidana. Bandung: Mandar Maju

[5] Shadily, Hassan. (2000). Kamus Besar Bahasa Indonesia. Jakarta: Gramedia

[6] Soekanto, Soerjono. (2004). Faktor-Faktor yang Mempengaruhi Penegeakan Hukum. Jakarta: Raja Grafindo Persada

[7] Supramono, Gatot. (2014). Hukum Uang Di Indonesia. Bekasi: Gramata Publising

[8] Wahid, Abdul and Mohammad Labib. (2005). Kejahatan Mayantara (Cyber Crime). Bandung: Refika Aditama

\section{Internet}

[1] Opinion, Highlighting the Moral Quality of Law Enforcers, quoted from /www.analisadaily.com/news/read/2011/12/10/, accessed on 29 November 2020, at 20.05 WIB 